\title{
COMPLETE ANDROGEN INSENSITIVITY SYNDROME IN THREE SISTERS: A CASE REPORT
}

\author{
Ozhan OZDEMIR, Mustafa Erkan SARI, Evren AKMUT, Gizem OZCANLI, Cemal Resat ATALAY
}

Department of Obstetrics and Gynecology, Ankara Numune Education and Research Hospital, Ankara

\begin{abstract}
SUMMARY
Complete androgen insensitivity syndrome (CAIS) (testicular feminization) is the most common cause of male pseudohermaphroditism. The underlying main pathology is an end organ resistance to androgen stimulation, and as a result, this impairs the differentiation of the body structures and systems which this hormone affects. Inheritance of this disorder is by means of an X-linked recessive gene that is responsible for the intracellular androgen receptors. CAIS may be observed in several members of a family. For this reason, the family members of the affected individual should be screened. In this article we present a case of three sisters diagnosed with CAIS after investigating the pedigree of one of them owing to an inguinal mass and diagnosing with CAIS.
\end{abstract}

Key words: complete androgen insensitivity syndrome, male pseudohermaphroditism, testicular feminization syndrome

Journal of Turkish Society of Obstetrics and Gynecology, (J Turk Soc Obstet Gynecol), 2014; Vol: 11, Issue: Pages:

\section{KOMPLET ANDROJEN DUYARSIZLIK SENDROMLU ÜÇ KIZ KARDEŞ}

\section{ÖZET}

Komplet androjen duyarsızlık sendromu (testiküler feminizasyon) erkek psödohermafroditizmin en sık nedenini oluşturur. Altta yatan temel patoloji androjen stimülasyonuna karşı end organ duyarsızlı̆̆ldır ve bunun sonucunda androjenlerin etki ettiği vücut yapıları ve sistemlerde farklılaşmayı etkileyen bir hastalıktır. Kalıtım şekli hücre içi androjen reseptörlerinden sorumlu olan X'e bağlı resesif bir gen ile ilişkilidir. Hastalık aynı ailenin birkaç ferdinde de görülebilir. Bu nedenle etkilenen bireylerin aile taraması yapılması gerekmektedir. Makalemizde inguinal bölgede kitle nedeni ile araştırılan ve komplet androjen duyarsızlık sendromu tanısı alan hastanın aile öyküsünün araştırılması ile ortaya çıkartılan komplet androjen duyarsızlık sendromlu üç kız kardeş olgusunu sunduk.

Anahtar kelimeler: androjen duyarsızlı sendromu, erkek psödohermafroditizm, testiküler feminizasyon sendromu

Türk Jinekoloji ve Obstetrik Derneği Dergisi, (J Turk Soc Obstet Gynecol), 2014; Cilt: 11, Sayl: Sayfa:

Address for Correspondence: Dr. Özhan Özdemir. Ankara Numune Eğitim ve Araştırma Hastanesi, Kadın Hastalıkları ve Doğum Kliniği, Ankara Phone: + 90 (505) 2255078

e-mail: seyozi@hotmail.com

Received: 04 September 2013, revised: 06 November 2013, accepted: 09 November 2013, online publication: 11 November 2013 


\section{INTRODUCTION}

Complete Androgen Insensitivity Syndrome (CAIS) was first described as 'Testicular Feminization' by Morris in 1953. It develops as a result of various mutations that inactivate the androgen receptor gene (1). The exact prevalance is not known although it is estimated to be seen in approximately $1 / 20.000$ 1/90.000 individuals with $46 \mathrm{XY}$ karyotype(2). Androgen receptor gene is located in the Xq11-12 region of chromosome $\mathrm{X}$, and androgen insensitivity syndrome (AIS) is inherited X-linked recessively. As a result of a resistance to androgenic activity, the body parts and systems affected by androgens are impaired. The clinical case varies according to the level of androgen resistance, characteristics of the individuals range from an infertile male to a proper female phenotype. AIS is classified in three different forms according to these characteristics as mild, partial and complete $^{(3)}$.

Most patients with CAIS have normal breast development in puberty but also have primary amenorrhea, a short and blind vagina, absence of pubic and axillary hairs along with absence of cervix and uterus. These patients with a $46, \mathrm{XY}$ caryotype have serum testosterone levels similar to normal males. The testicles are generally located in the inguinal canal but may also be intraabdominal so the exact location must be identified by ultrasonography (USG) or magnetic resonance imaging (MRI) ${ }^{(4)}$.

Androgen Insensitivity Syndrome is inherited X-linked recessively, and every one of three phenotypically female sisters or every one of six daughters of normal sisters of the affected individual has a risk of carrying an XY phenotype. Therefore a family screening of the affected individual should be performed. There are reports of siblings with CAIS in the literature but there are limited cases with three sisters ${ }^{(5,6)}$. Herein we describe three sisters with a diagnosis of CAIS.

\section{CASE}

A 41-year old married woman applied to our clinic with a mass in the left inguinal region. The patient told she had never had menstruation. A $15 \times 10 \mathrm{~cm}$ mobile mass was detected in the left inguinal region along with a $4 \times 3 \mathrm{~cm}$ solid, mobile mass in the right inguinal region in clinical examination. The external genital organs were in female phenotype with a $6 \mathrm{~cm}$ blind vagina. Her breast development was normal but there were no axillary or pubic hairs. No uterus or ovaries were observed by USG and MRI, but a 137x80x124 $\mathrm{mm}$ solid mass with septal and polipoid extensions with a regular surface was detected in the left inguinal region lying from the hip joint to the level of labium majus (Picture 1). There was also a 32×28 mm solid mass in the right inguinal region. The patient's follicular stimulating hormone (FSH) was found to be 9.68 $\mathrm{mIU} / \mathrm{mL}$, luteinizing hormone $(\mathrm{LH})$ was 15.74 $\mathrm{mIU} / \mathrm{mL}$, estradiol was $56.07 \mathrm{pg} / \mathrm{mL}$ and total testosterone was $1.83 \mathrm{ng} / \mathrm{mL}$.

Picture 1: The macroscopy of the gonadal mass in the inguinal region of the first patient diagnosed.

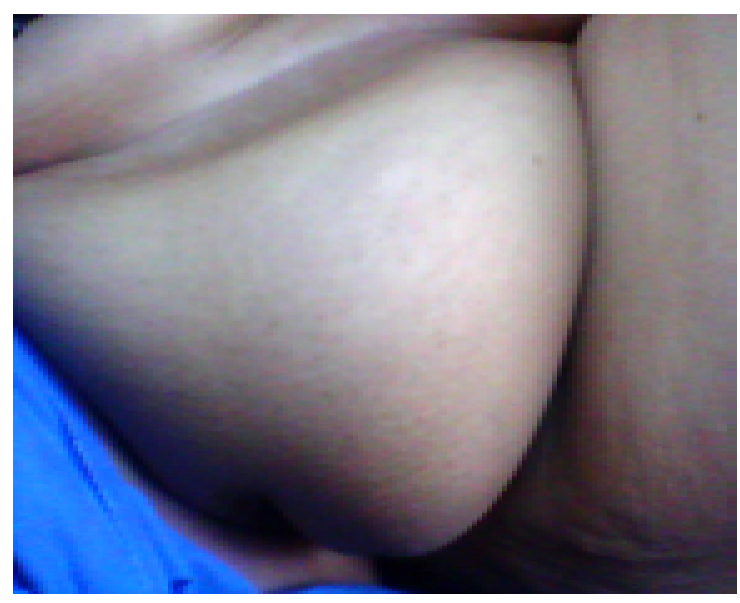

She had three sisters who were 44, 32 and 30 years old. The 44-year old sister had a regular menstruation, and also gave birth to children. But the other two sisters were learned to have no menstruation, and were married with no children. Thereupon, these three sisters were called for examination. The 44-year old sister's exam was found normal but the other two sisters were seen to have $6 \mathrm{~cm}$ long blind vaginas, with no axillary or pubic hairs, but with normal breast developments. Three $\mathrm{cm}$ mobile masses were palpated in inguinal canals of both sisters. There were no uterus or ovaries seen by USG and MRI in both.

A peripheral caryotype analysis was held with a prediagnosis of CAIS in the patient and the two sisters. The caryotypes were found to be $46, \mathrm{XY}$ with the method of lymphocyte tissue culturing from peripheral blood. The eldest sister was found to be $46, \mathrm{XX}$ by using the same method (Table I). The pedigree of the 
Table I: The distribution of the phenotype, genotype, and hormonal profiles of the cases.

\begin{tabular}{|c|c|c|c|c|c|c|c|c|c|}
\hline & Age & Phenotype & Karyotype & $\begin{array}{l}\text { Axillary/ } \\
\text { Pubic } \\
\text { Hairs }\end{array}$ & $\begin{array}{l}\text { LH } \\
(\mathrm{mIU} / \mathrm{mL})\end{array}$ & $\begin{array}{l}\text { FSH } \\
(\mathrm{mIU} / \mathrm{mL})\end{array}$ & $\begin{array}{l}\text { Estradiol } \\
(\mathrm{pg} / \mathrm{mL})\end{array}$ & $\begin{array}{l}\text { Total } \\
\text { Testosterone } \\
(\mathrm{ng} / \mathrm{mL})\end{array}$ & Diagnosis \\
\hline Sister 1 & 44 & Female & $46 \mathrm{XX}$ & Yes & 6,12 & 8,11 & 51,15 & 0,24 & Normal \\
\hline Sister 2 & 41 & Female & $46 \mathrm{XY}$ & No & 15,74 & 9,68 & 56,07 & 1,83 & CAIS \\
\hline Sister 3 & 32 & Female & $46 \mathrm{XY}$ & No & 16,21 & 8,72 & 62,14 & 1,95 & CAIS \\
\hline Sister 4 & 30 & Female & $46 \mathrm{XY}$ & No & 15,25 & 9,57 & 61,57 & 1,87 & CAIS \\
\hline
\end{tabular}

CAIS: Complete Androgen Insensitivity Syndrome.

family is shown in Table II.

Bilateral gonadectomy was planned in the three sisters diagnosed with CAIS. Testicular tissue was detected in the right inguinal region of the 41-year old sister along with serous papillary cystadenoma in the left one. The other two sisters refused to have surgery.

Table II: The Family Pedigree.

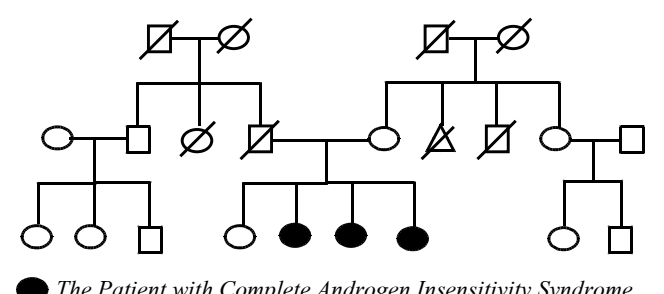

DISCUSSION

Androgen Insensitivity Syndrome is inherited X-linked recessively, and every one of three phenotypically female sisters or every one of six daughters of normal sisters of the affected individual has a risk of carrying an XY phenotype. Therefore a family screening of the affected individual should be performed. De novo mutations are probably responsible in individuals with no family history, and this kind of mutation rate is more than $30 \%$ in patients with CAIS ${ }^{(7)}$.

The androgen receptors are expressed in the 8th pregnancy week in the male embryo, and the testicles start to produce testosterone in the $9^{\text {th }}$ week. Testosterone production peaks between $11^{\text {th }}$ and $18^{\text {th }}$ week, and this causes the mesonephric canals to differentiate into epididymis, vas deferens and seminal vesicules. In CAIS, a resistance to androgens develops as a result of a defect in androgen receptor, and these structures needing androgens for embryological evolvement cannot be developed. In the meantime, antimullerian hormone $(\mathrm{AMH})$ is secreted from the testicles and the development of paramesonephric canal is inhibited. For this reason the tubes, uterus and 2/3 upper part of vagina, which originates from paramesonephric canal, are also not developed $^{(8)}$.

Development of the male external genital system depends on the stimulation of a more potent androgen called dihydrotestosterone, and this hormone is essential for the urogenital sinus to differentiate into male phenotype. In CAIS, the urogenital sinus is differentiated into female phenotype as a result of the defect in androgen receptors. But as there is no differentiation of mullerian structures, the upper part of vagina is not developed. For this reason, even the external genitalia are in female phenotype, the vagina is short and blunt ${ }^{(8)}$. On the other hand, although the testicles may be found in the abdominal region, with the effect of AMH they are usually located in the inguinal canal or labia majus. The histology resembles of undescended testis; there are normal or increased number of Leydig cells without spermatogenesis. Immature seminiferous tubules surrended by immature germ cells and sertoli cells are observed.

Axillary and pubic hairs are not seen in CAIS because of androgen insensitivity, but breast development occurs due to the effect of unfulfilled estrogen occuring as a result of peripheric aromatization of androgens. These patients are taller and heavier than normal women, but they have female phenotype and sexual characteristics as general body habitus ${ }^{(8)}$.

Serum testosterone concentrations are normal or mildly elevated in puberty in individuals with CAIS, but because there is no negative feedback effect of the androgens to the hypothalamo-hypophyseal portal system, the frequency and pulsatility of LH secretion increase. Despite that, FSH and inhibin levels are usually normal. On the other hand, estrogen production due to peripheric aromatization of androgens is $70 \%$ higher than normal men ${ }^{(9)}$. 
In a pregnancy which prenatal diagnostic tests like amniosynthesis are applied, and karyotype is found to be 46, XY, the diagnosis of CAIS is easily made in a female phenotypic baby following the birth. Despite that, the patients usually apply with a mass in groin in neonatal period or with primary amenorrhea in adolescent period. The incidence of CAIS is $1-2 \%$ in female phenotypic newborns with bilateral inguinal hernia. Therefore, CAIS should be suspected in primary amenorrheic patients presenting with unilateral or bilateral inguinal hernia or labial mass. Another reason for applying to doctor is a pelvic mass owing to a gonadal tumor, particularly in the inguinal region ${ }^{(10)}$. The first patient in our report was also diagnosed while being investigated because of an inguinal mass.

Appropriate hormone replacement therapy, generating a functional vagina, performing gonadectomy following puberty for avoidance of tumor development, and physocological support should be aimed in the treatment of these patients. Estrogen replacement therapy should be planned following gonadectomy. Vaginal dilatators are efficient and should be the first choice of treatment, and vaginal surgery is rarely needed for reconstructing a functional vagina. Vaginoplasty may be applied in requiring cases ${ }^{(11)}$. In our cases, we did not need any additional approach as all three sisters had vaginas suitable for sexual intercourse.

There is a risk of malignancy in undescended testicle tissue in CAIS and this risk increases more than $30 \%$ in patients who do not undergo gonadectomy. As the pubertal development progresses regularly depending on endogeneous hormones and the risk of gonadal tumor development is rather low (5-10\%) before puberty, the ideal time for gonadectomy is after puberty (approximately 16-18 years of age) ${ }^{(12)}$. In patients who do not undergo gonadectomy the incidence of developing gonadal tumors in 25 and 50 years of age is 3,6\% and $33 \%$, respectively ${ }^{(13)}$. Certain number of patients do not accept gonadectomy despite this increasing risk of gonadal tumor development, and monitorization methods should be used in follow-up. Our two cases with CAIS diagnosis rejected gonadectomy and was joined the follow-up procedure.

In conclusion, as CAIS is a maternally X-linked recessive inheriting disorder, the female newborns are $50 \%$ a carrier, and the male newborns are $50 \%$ ill, so the other siblings of the patient who are female in phenotype should be investigated by the means of this syndrome. Also, couples who have a history of child birth with CAIS of their own or in their family, should take genetic consultation.

\section{REFERENCES}

1. Morris JM. The syndrome of testicular feminization in male pseudohermaphrodites. Am J Obstet Gynecol. 1953;65(6): 1192-211.

2. Boehmer AL, Brinkmann $\mathrm{O}$, Brüggenwirth $\mathrm{H}$, van Assendelft C, Otten BJ, Verleun-Mooijman MC, et al. Genotype versus phenotype in families with androgen insensitivity syndrome. J Clin Endocrinol Metab 2001;86(9):4151-60.

3. Pizzo A, Laganà AS, Borrielli I, Dugo N. Complete androgen insensitivity syndrome: a rare case of disorder of sex development. Case Rep Obstet Gynecol. 2013;2013:232696.

4. Quigley CA, De Bellis A, Marschke KB, el-Awady MK, Wilson EM, French FS. Androgen receptor defects: historical, clinical, and molecular perspectives. Endocr Rev. 1995;16(3): 271-321.

5. Likourinas M, Conidaris D, Alivizatos G, Dimopoulos MA. Complete testicular feminisation syndrome in three sisters. Br J Urol 1990;65(3):298-9.

6. Kokcu A, Otken G, Kara N, Elbistan M. Complete testicular feminization syndrome in three sisters. Turkiye Klinikleri J Gynecol Obst 1992;2(3):213-7.

7. Leslie ND. Haldane was right: de novo mutations in androgen insensitivity syndrome. J Pediatr 1998;132(6):917-8.

8. Hannema SE, Scott IS, Hodapp J, Martin H, Coleman N, Schwabe JW, et al. Residual activity of mutant androgen receptors explains wolffian duct development in the complete androgen insensitivity syndrome. J Clin Endocrinol Metab 2004;89(11):5815-22.

9. Galani A, Kitsiou-Tzeli S, Sofokleous C, Kanavakis E, KalpiniMavrou A. Androgen insensitivity syndrome: clinical features and molecular defects. Hormones 2008;7(3):217-29.

10. Stewart CJR, Baker E, Beaton C, Crook M, Peverall J, Wallace S. Detection of Y-chromosome in gonadal tumours using fluorescence in situ hybridization: diagnostic value in intersex conditions including older patients with clinically unsuspected androgen insensitivity syndrome. Histopathology 2008;52(2): 175-82.

11. Ismail-Pratt IS, Bikoo M, Liao LM, Conway GS, Creighton SM. Normalization of the vagina by dilator treatment alone in Complete Androgen Insensitivity Syndrome and MayerRokitansky-Kuster- Hauser Syndrome. Hum Reprod 2007; 
22(7):2020-4.

12. Deans R, Creighton SM, Liao LM, Conway GS. Timing of gonadectomy in adult women with complete androgen insensitivity syndrome: patient preferences and clinical evidence. Clin Endocrinol 2012;76(6):894-8.

13. Yanai Y, Hiroi H, Osuga Y, Fujimoto A, Momoeda M, Yano $\mathrm{T}$ at al. Androgen insensitivity syndrome with serous gonadal cyst. Fertil Steril 2008;90(5):2018.e9-11. 